\title{
Network value analysis of the pharmaceutical assistance in Porto Alegre city: a systemic view
}

\author{
Luiza Tanaka Leães , André Teixeira Pontes ${ }^{b}$, Istefani Carísio de Paula a, Elaine Regiani de Camposa , Edyane Cardoso Lopesc, \\ Fernando Maracci Martins ${ }^{a}$, Leonel Augusto Morais Almeida ${ }^{d}$ \\ aniversidade Federal do Rio Grande do Sul - UFRGS \\ UUniversidade Federal Fluminense - UFF \\ Secretaria de Estado de Saúde do Rio Grande do Sul - SES

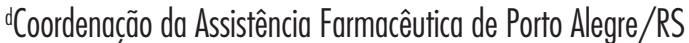 \\ e-mails: luiza.t|@live.com; atpontes@id.uff.br; istefanicpaula@gmail.com; earcamp@gmail.com; edyanelopes@hotmail.com; \\ nandomaracci@hotmail.com; leonel.almeida@sms.prefpoa.com.br
}

\begin{abstract}
The Pharmaceutical Service (PS) involves a set of drug-related processes, including all logistic movement and promotion of rational use of these products. To deliver the desired value to the users of the health system, the PS network consists of several actors interacting to perform a set of activities, classified in selection, programming, acquisition, storage, distribution and dispensing of medicines (S-P-A-S-D-D). The objective in this research was to test the application of Value Network Analysis in a complex health process. The construction of value network of the PS happened through workshops with the managers of the PS of the municipality of Porto Alegre. As a result, it was observed that the graphical representation provided by the NVA tool, at first, surprised the managers involved, when observing the complexity of the tangible and intangible flows exchanged between the actors of the network. The analysis of the network led to the restructuring of functions and reallocation of pharmaceutical professionals, increasing the number of pharmacists acting directly in the district pharmacies, and structuring a support position for the management of the logistics processes. The changes take place by improving the overall performance of the professionals without any increase in staff or additional expenses with salaries.
\end{abstract}

Keywords: network value analysis, pharmaceutical service, systemic view.

\section{Introduction}

One of the vital inputs to health processes is the drugs, whose demand is increasing mainly due to the aging of the population (PINTO; OSORIO-DE-CASTRO, 2015). The management of all drug-related processes, including the promotion of rational use, is called Pharmaceutical Service (PS). It is defined as a set of actions and services aimed at ensuring full therapeutic care and the promotion, protection and recovery of health in public and private establishments that carry out pharmaceutical activities, having the medicine as an essential input and aiming at its access and its rational use (BRASIL, 2014). It also involves the research, development and production of medicines and supplies, as well as their selection, programming, acquisition, distribution, dispensing, quality assurance of products and services, monitoring and evaluation of their use, with a view to obtaining results the quality of life of the population (BRASIL, 2004). Given the complexity of the system this becomes an important field of application of engineering tools.

According to the Association Française de Normalization (ASSOCIATION..., 2000), the concept of value is based on the relation between the satisfaction of many different needs and the resources used for this. The lower the amount of resources used or the greater the satisfaction of needs, the greater the value. In the context of PA, this represents the availability of the medicines to the population and a set of services that contribute to these drugs generating the desired therapeutic effect. Processes related to pharmaceutical care are vectors of the generation of drug value for the end user.

In a value chain, value creation is derived from products, and to the extent that products match customer needs, they define the source of competitive advantage. It consists of a linear structure of processes for the production of tangible and intangible goods, with flow of products and capital organized in a linear and opposite way. The value network, 
on the other hand, creates value by exchanging benefits between the parties involved and reverses the competitive advantage insofar as the network in which these exchanges are enabled corresponds to the needs and objectives of its members (FJELDSTAD; KETELS, 2006). In the network the flows are simultaneous and the links have multiple roles.

It is understood that PHC operates in a network and not in a chain of value, making each link essential for the success of the system. Providing network visibility is essential to make each stakeholder aware of its role, as well as providing a baseline for measurement and consequent optimization. The question that arises is how the tools of value analysis proposed for the industrial environment would behave in other segments such as health?

This research presents the application of Value Network Analysis in a complex health process. The unit of analysis is an ongoing experiment in the development of the Pharmaceutical Service value network of the city of Porto Alegre - RS, Brazil, using the Value Network Analysis tool. The theoretical contribution is to feed the literature with applications of the tool in the health environment. The practical contribution is to provide a systemic view for the actors of the network, providing a basis for optimizing processes in terms of tangible and intangible flows.

\section{Literature review}

In this item will be presented the theoretical bases that support the project.

\subsection{Primary Health Care (PHC) and Pharmaceutical Service (PS)}

The Brazilian public health network is complex because of its extension, so it is operated hierarchically involving the federal, state and municipal spheres. Primary Health Care (PHC) represents the first contact of individuals with the Unified Health System (SUS) (BRASIL, 2017), offering the services of lower complexity, but with great demand and capillarity.

The profile of the Brazilian municipalities, with limited resources, gives an idea of the challenge of providing the basic health care system with the necessary resources to care for the Brazilian population. It should also be considered that Brazil is the only country in the world with more than 100 million inhabitants to have a public health system, universal, integral and free (BRASIL, 2017). Thus, increasing pressure for improved care, by increasing productivity and reducing costs, requires activities focused on the control and optimization of care processes, increasing their efficiency and effectiveness (PAPADOPOULOS et al., 2015)

Papadopoulos et al. (2015) identified among the main problems of basic care in Greece, the high cost of medicines to meet the needs of the population and the cost increase with new therapeutic schemes, which may involve new medicines and expensive exams. All the actions of selection, programming, acquisition, storage, distribution and dispensing of medicines (S-P-A-S-D-D) are understood by the PA, and evolve the operationalization by professionals who work in the context of a logistical support service, and the provision of care services to the in order to support the proper use of medicines. Structuring pharmaceutical care is one of the great challenges for SUS managers, both for the financial resources involved and for the need for continuous improvement with the search for new management strategies (BRASIL, 2007).

\subsection{Network Value Analysis (NVA)}

The concept of value is based on the relationship between the satisfaction of many different needs and the resources used for it. The lower the amount of resources used or the greater the satisfaction of needs, the greater the value (ASSOCIATION..., 2000). In the health sector, according to Porter (2010) it is important to consider the concept of value for the patient, whose needs are more related to quality of life and improvements in health conditions.

Due to profound changes in the global competitive context, Porter's (1989) concept of the value chain, which decomposes the company into fundamental activities and aims to understand the impact of these activities on cost and value through a logic of direct transformation of inputs in products, no longer adequately describes the mechanisms of action of all companies. In this sense, Rocha and Borinelli (2007, p. 149) consider that: "[...] value chain is a sequence of activities that starts with the origin of resources and goes to the disposal of the product by the last consumer." Rocha and Borinelli, (2007) mention that the concept became more complete since it involved the origin of the resources until the last consumer, thus covering the entire life of the product until its final disposal (recycling or destruction), including resources such as information, materials, technology, and human resources.

According to Fjeldstad and Ketels (2006), the value chain does not adequately represent business flows that create value from intangible solutions such as information packages and services such as telephony. Thus, Fjeldstad and Ketels (2006) developed another value network configuration proposal, as an alternative to non-product-centric business, called Network Value Analysis (NVA). According to the authors, value network configurations are important tools for analyzing the strategic positioning of companies, especially in relation to their relationships with stakeholders, although they are not as effective as operational efficiency.

Network Value Analysis (NVA) is a method that generates a visual representation of the tangible and intangible flows exchanged between the parties involved 
in a value network, in which the critical relations for the success of the system are highlighted. At a more strategic level, considering their relations and linearities, it does not focus on possible relations of dominance between one part and another. The objective is to generate a comprehensible description of where the value is and how it is created from a visual construct of what can be observed in the reality of the network (PEPPARD; RYLANDER, 2006; FJELDSTAD; KETELS, 2006). Donaldson, Ishii and Sheppard (2006) show that this representation must interpose between the strategic objectives statements and the operation, providing a shared vision of the system for all involved.

Following these guidelines, the result will be a detailed description of how it is created and where the value is in a given network. The application of the NVA according to Peppard and Rylander (2006) presupposes: to define the objectives, describing where it is value in the network; identify and define the participants, who and how they influence the flow; identify the dimensions of value of the participants, what they perceive about the tangible and intangible flows that are exchanged in the provision of value; as well the analysis and form of the value network, for future scenarios proposition.

The first step, defining the objectives of the network, implies in considering the network as a construction that connects several groups in favor of the common objective of production of value perceived by each one. The definition of who the members of this network are considers all those that influence or are affected by the main business model to be analyzed, which was previously determined. To deliver value it is necessary to understand what is really desired by each of the components of the network and, consequently, for the chain as a whole. It also requires the understanding of the reason why an entity is part of the system, as well as the obstacles and objections perceived by them that may reduce the dimensions of value.

Still following the model created by Peppard and Rylander (2006), there is the possibility of finding some divergences between the stakeholders in terms of both benefits and losses, and it is important to identify and classify such differences. This information allows to determine the responsibility of doing or not of each member of the value network, in addition to influencing the development of relationships in the network. With this information, it is possible to understand and define how the different points of view connect, whether in the form of control, dependency, inspection, etc. These links can be called influences, which serve as indicators for how much participants should consider when developing a business model, and are divided into:

a) exchange of goods and services; b) affection and connection (emotional);

c) information and ideas; and

d) influence and power.

Finally, we seek to analyze and model the value network map, generating a systemic view from which one can obtain conclusions about the roles of each of the stakeholders in different scenarios and their relationships with the others.

The application of NVA requires the definition of the business model and its objectives for the process, followed by the determination of stakeholders. Determine how each component is related to the others, identifying their relationships from the definition of the flows established between them, and then analyze the results in order to determine critical or fundamental consumers and their value perspectives is a common feature of both tools. The fundamental difference between NVA and Costumer Value Chain Analysis (CVCA) from Donaldson, Ishii and Sheppard (2006) may lie in the way in which each one deals with those involved in the network since, in CVCA all constituents of the network, including stakeholders, are considered consumers. Although both the NVA and CVCA tools reach the main objective of proposing a mapping of the tangible flows, the NVA stands out in the way in which it perceives the value proposition of the network and therefore evaluates the flows intangible assets. In addition, considering the coincidence between the proposals of Donaldson et al. (2006) and Peppard and Rylander (2006) in their first steps, the terms for this article were adopted as synonyms, disregarding the last two steps of the CVCA that do not fit the objectives of the reported project but rather for product development.

\section{Method}

\subsection{Unit of analysis}

The research was developed in the city of Porto Alegre, located in the southern region of Brazil, which has about 1.5 million people (INSTITUTO..., 2018). In the context of the Brazilian Unified Health System (SUS), the city of Porto Alegre purchases medicines for free distribution to the population. The drugs purchased are stored in a distribution center (CAF) and they are later distributed to 10 District Pharmacies (DP) and more than 160 Health Units (HU), where the population of the city can withdraw the medicines.

This entire process is managed by the Coordination of Pharmaceutical Service (COORAF) and counts on the direct participation of pharmaceutical professionals in various points of the process, from the most operational part, in the District Pharmacies, as well as in the managerial and strategic processes, in COORAF. 


\subsection{Research steps}

The construction of the value network of the pharmaceutical service in the city of Porto Alegre was carried out through workshops with 3 COORAF managers. There were 4 meetings lasting approximately 4 hours each. At these meetings, the value network analysis tool (NVA) was applied in the following steps, presented in Table 1, adapted to meet the needs of the system in question:

Once the value network flow mapping meetings were held, visits to selected District Pharmacies (DP) were scheduled. The choice of DP considered factors such as accessibility of the pharmacist responsible, physical dimensions of the site, volume of visits per day and relevance to the others. From these visits, and with the flows at hand, it was possible to recognize and understand the difficulty in working with the entire network simultaneously for its length and complexity.

\section{Results and discussion}

The main fundamental objective in the case reported in this paper follows the aforementioned assumptions regarding the primordial notion of value in health systems, however, it is believed that in order to achieve such a broad and complex goal it is necessary to understand essential parts of the system. The Network Value Analysis procedure has proven to be suitable for this purpose.

The sensitization meeting met the needs of the current COORAF managers who, assuming management at the end of 2017, needed a strategic management tool. Therefore, the acceptance of the NVA application was immediate. The NVA is a business management tool and needed to be adapted for application in the health segment

The first step of applying the NVA involves consulting the company's business plan for answers. Because this is a health coordination, which does not have a business plan, the issues were modified according to need and answered by the managers themselves. Table 2 summarizes some questions and answers.

Table 1. Realized meetings description.

\begin{tabular}{|c|l|}
\hline Meetings & \multicolumn{1}{c|}{ Descripton } \\
\hline Meeting 01 & $\begin{array}{l}\text { Awareness Raising - At that time, the NVA methodology was presented for the COORAF team and it was performed } \\
\text { a detailed explanation of the objectives of the construction of the value network. }\end{array}$ \\
\hline Meeting 02 & $\begin{array}{l}\text { Identification of stakeholders and their needs - During the second meeting, a questionnaire was applied with the } \\
\text { intention of gathering the following information: target public of the PA; the PA differential for users in COORAF's } \\
\text { view; which is considered essential in the context of PA for COORAF; What COORAF considers essential for the } \\
\text { user; which is unique in the AF of Porto Alegre that allows to deliver the benefits to the users. Next, a list of actors } \\
\text { interacting with the PA of the municipality was elaborated. Finally, it was built, using Lucid Table }{ }^{\circledR} \text { web application } \\
\text { software, the design of a first flow of relations between the mentioned actors. }\end{array}$ \\
\hline Meeting 03 e 04 & Elaboration of the value network - these meetings were focused on the construction of the value network. \\
\hline Completion & Evaluation of the value network by managers and identification of improvement opportunities. \\
\hline
\end{tabular}

Table 2. Summary of NVA application questions and answers.

\begin{tabular}{|l|l|}
\hline \multicolumn{1}{|c|}{$\begin{array}{c}\text { Questions about the structure of the } \\
\text { AF value network }\end{array}$} & COORAF managers replies \\
\hline $\begin{array}{l}\text { Who is the target audience for the AF } \\
\text { network? }\end{array}$ & $\begin{array}{l}\text { All users, residents of Porto Alegre, who wish to access medication through SUS within the } \\
\text { municipality. }\end{array}$ \\
\hline $\begin{array}{l}\text { What is the difference between PA and } \\
\text { users? }\end{array}$ & $\begin{array}{l}\text { Decentralized access is a beneficial differential for the user, but not for management control } \\
\text { (an intermediate situation might be more appropriate). There are 10 District Pharmacies (DP), } \\
\text { distributed in 8 managements, where the clinical pharmacy is being implemented. }\end{array}$ \\
\hline Who supplies the inputs? & $\begin{array}{l}\text { The capital is provided from three donors: the municipality, the state and the ministry of health. } \\
\text { GRANPAL, a consortium between the municipalities of the greater Porto Alegre and the border, } \\
\text { assists in the negotiation to acquire a large part of the medicines. Requests in general are decentralized } \\
\text { and COORAF draws up the necessary quantities for each pharmacy. }\end{array}$ \\
\hline $\begin{array}{l}\text { What distribution channels are used? } \\
\text { (...) }\end{array}$ & $\begin{array}{l}\text { The Pharmaceutical Supply Center (CAF) receives the medicines from the suppliers, separates by } \\
\text { lot, validity and other criteria considered relevant to then distribute according to what was selected. }\end{array}$ \\
\hline $\begin{array}{l}\text { What is considered essential in the } \\
\text { context of PA for COORAF-POA: }\end{array}$ & $\begin{array}{l}\text { Access to the drug, then avoiding losses, rational use of medicines (first the logistics of the medicine } \\
\text { - computerization in the DP (already started), profile of use, who is the target audience for clinical } \\
\text { care, in which public the pharmacist is more effective, then implemented properly) }\end{array}$ \\
\hline $\begin{array}{l}\text { What is essential from the user's point } \\
\text { of view in relation to PA? }\end{array}$ & Access to the drug, pharmaceutical care. \\
\hline $\begin{array}{l}\text { What is unique about the PA of Porto } \\
\text { Alegre that allows its managers to } \\
\text { deliver the benefits to the users? }\end{array}$ & $\begin{array}{l}\text { Highly qualified human resources, open generation the implementation of pharmaceutical care, } \\
\text { teaching-service relationship in training, associated to the regulatory sector. The support network } \\
\text { of the professional councils has given the necessary support. }\end{array}$ \\
\hline
\end{tabular}


Once the questions were answered, the design of the flows starting from the end-user's access to the drug, which occurs in the relationship with the District Pharmacy, towards the flows that allow the drug to arrive at the pharmacy within the appropriate time limits, in the quantities needed. Throughout two meetings the relationships between the tangible and intangible flows of the PA selection, programming, acquisition, storage, distribution and dispensation sub processes were detailed.

The main result to date is the graphical representation of the built-value network, which allowed COORAF managers to have a complete view and, therefore, the complexity of the relationships present in the sub process of programming of monthly orders and distribution of medicines (Tables 3 and 4 and Figures 1 and 2). This was reported by them during the meetings as a great benefit and allowed for an initial identification of improvement opportunities. Although there is a specific phase for the analysis of the network and proposing improvements, it is natural that those involved already detect elements that can be modified.

The complexity of the system is revealed by the existence of more than 30 involved parties, so the figure representing the overview was deployed in S-P-A-S-D-D sub processes, special drug programs (women's health, tuberculosis, black and indigenous health, HIV / AIDS) and the treatment of diabetes. The mapping of the S-P-A-S-D-D processes is not described in this article, and it is emphasized the sub process scheduling of monthly orders and drug distribution that was modified in the initial phases of the study and presented in Tables 4 and 5 and in Figures 1 and 2. Table 4 seeks to compile these relationships prior to processes modifications.

Improving the flows that related the District Pharmacy to other agents of the network was of fundamental importance,

Table 3. Description of relations with the District Pharmacy: Before modifications.

\begin{tabular}{|c|c|c|c|}
\hline Local & Acronyms & Description & Input/Output \\
\hline \multirow{4}{*}{ US } & LR-1 & Reverse Logistics: Excess, overdue or damaged medicines. & Receptor \\
\hline & E22 & Emergency Medication Requests & Receptor \\
\hline & Mtt & Medicines for tuberculosis and tamiflu & Supplier \\
\hline & $\mathrm{Mb}$ & Basic medicines & Supplier \\
\hline \multirow{2}{*}{ SAE } & E22 & Emergency Medication Requests & Receptor \\
\hline & $\mathrm{Mb}$ & Basic medicines & Supplier \\
\hline \multirow{2}{*}{ ILPI } & $\mathrm{R}$ & Prescription & Supplier /Receptor \\
\hline & $\mathrm{M}$ & Medications (all) & Supplier/Receptor \\
\hline CAPS & $\mathrm{M}$ & Medications (all) & Supplier \\
\hline PA & LR-2 & Reverse logistics: medicines still in use, which would not be consumed in the HU. & Supplier \\
\hline \multirow{4}{*}{ FA } & DG-2 & General demands: information, doubts & Receptor \\
\hline & $\mathrm{S}$ & Requests for medicines, devices, $\ldots$ & Supplier \\
\hline & I_LFS & Information related to diabetes needs consumption & Supplier \\
\hline & I_LR-1 & Reverse Logistics Information & Supplier \\
\hline GD & DG-1 & General demands: collection of missing information and other identified problems & Receptor \\
\hline PMDID & Ilog_LFS & Logistics information related to diabetes supplies. & Supplier \\
\hline \multirow{3}{*}{ CAF } & LR-1 & Reverse Logistics: Excess, overdue or damaged medicines. & Supplier \\
\hline & $\mathrm{M}$ & Medications (all) & Receptor \\
\hline & $\mathrm{LFS}+\mathrm{AP}$ & Inputs for diabetes & Receptor \\
\hline
\end{tabular}

Table 4. Description of relations with the District Pharmacy: after modifications.

\begin{tabular}{|c|c|l|c|}
\hline Local & Acronym & \multicolumn{1}{|c|}{ Description } & Input/Output \\
\hline \multirow{4}{*}{ COORAF } & S & Request for medicines, devices and supplies for diabetes. & Supplier \\
\cline { 2 - 5 } & I_LFS & Information related to LFS consumption & Supplier \\
\cline { 2 - 5 } & I_LR-1 & Reverse Logistics Information & Supplier \\
\cline { 2 - 5 } & DG & General demands: collection of missing information and other identified problems & Supplier \\
\hline \multirow{2}{*}{ ILPI } & S & Request for medicines, devices and supplies for diabetes. & Supplier /Receptor \\
\cline { 2 - 5 } & M & Medications (all) & Receptor \\
\hline GD & DG-1 & General demands: collection of missing information and other identified problems & Supplier \\
\hline PMDID & Ilog_LFS & Logistics information related to diabetes supplies. & Supplier \\
\hline \multirow{3}{*}{ CAF } & LR-1 & Reverse logistics: over, overdue or damaged drugs. & Receptor \\
\cline { 2 - 5 } & M & Medications (all) & Receptor \\
\cline { 2 - 5 } & LFS + AP & Inputs for diabetes & \\
\hline
\end{tabular}




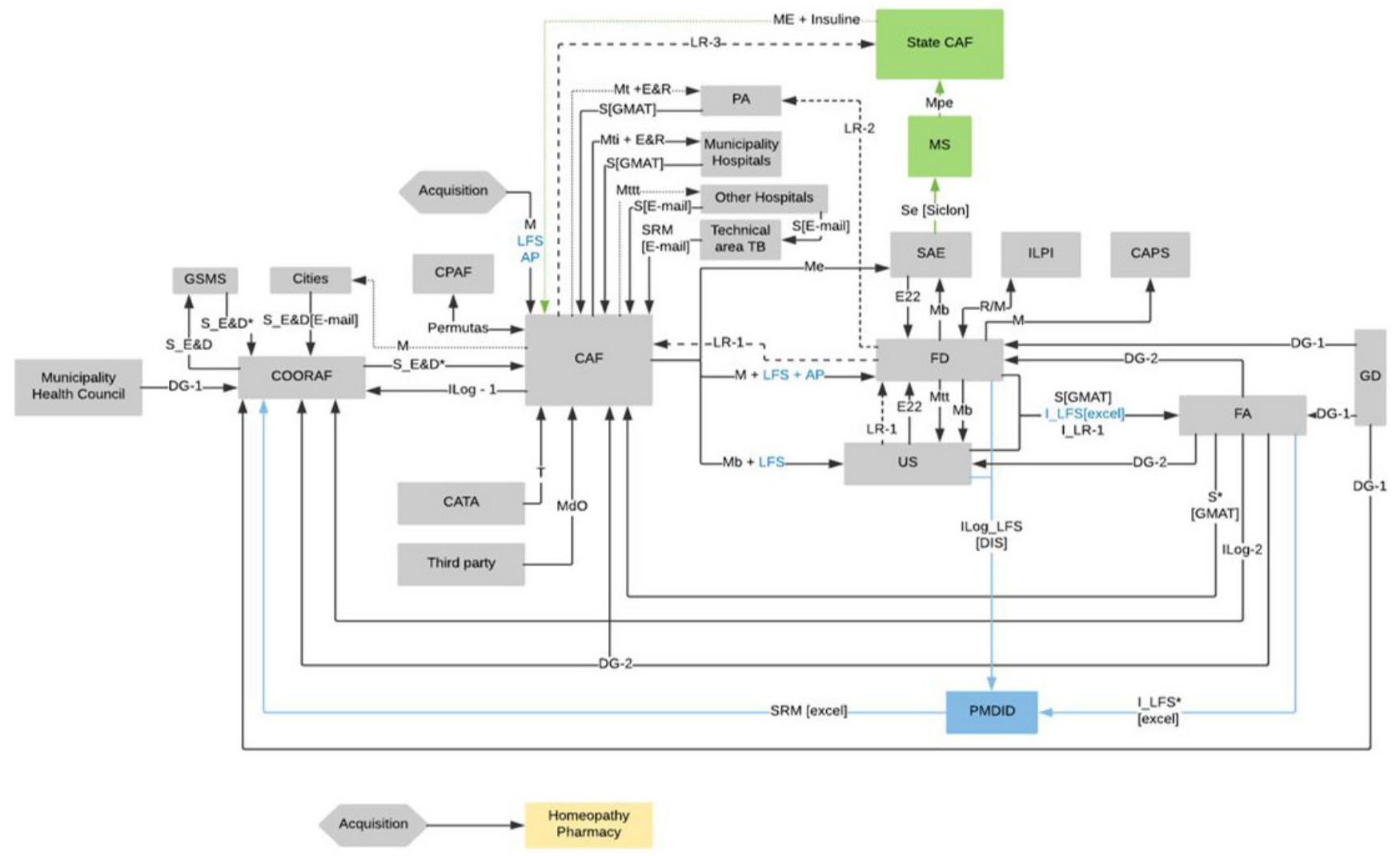

Figure 1. Schedule of Monthly Orders and Distribution: Before Modification. Legend: Direct Flows; Reverse Flows.

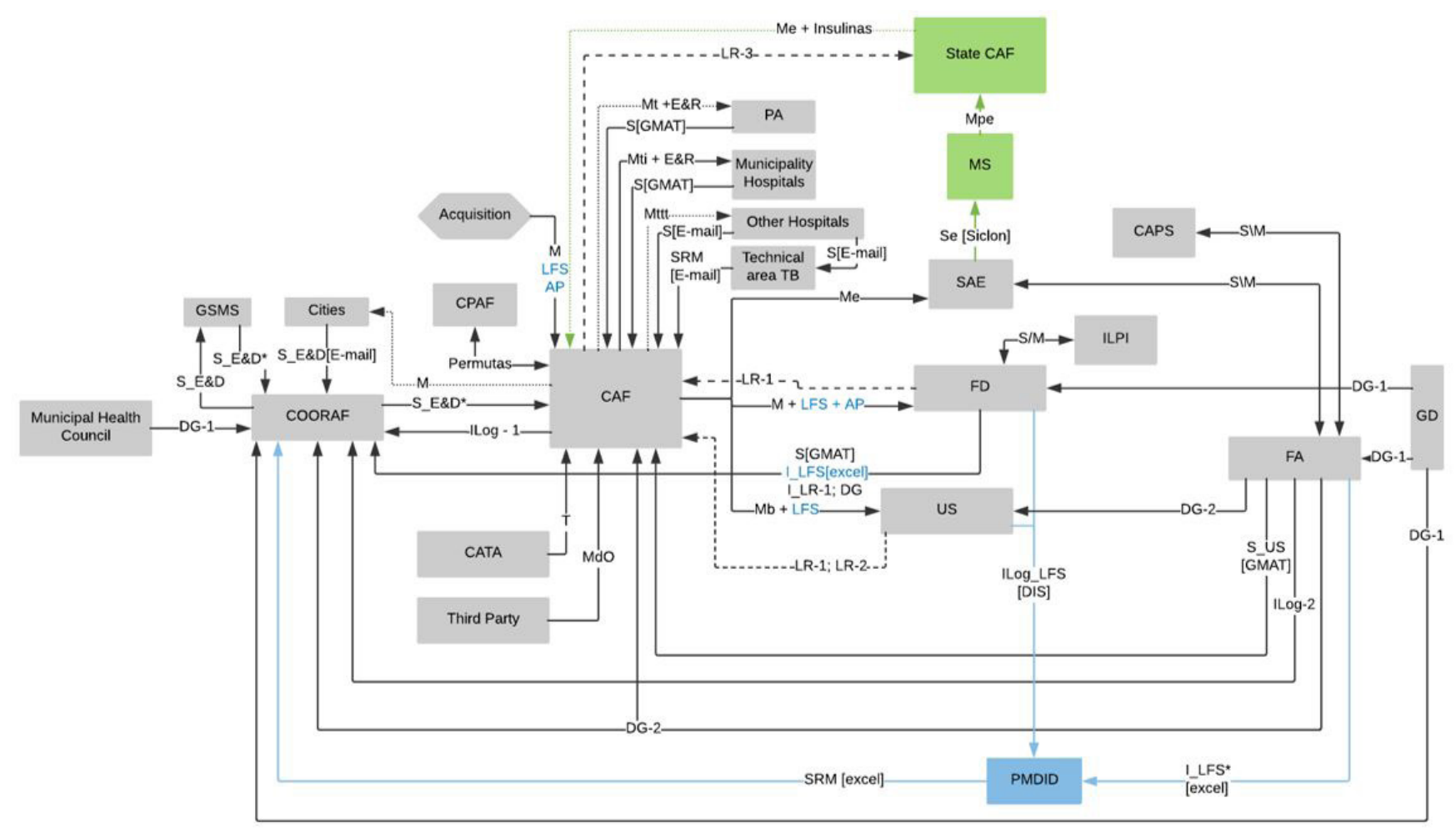

Figure 2. Schedule of Monthly Orders and Distribution: After Modification. Legend: Direct Flows; Reverse Flows. 
Table 5. Description of work fronts.

\begin{tabular}{|l|l|l|}
\hline \multicolumn{1}{|c|}{ Work Front } & \multicolumn{1}{|c|}{ Objective } & \multicolumn{1}{|c|}{ Tasks } \\
\hline Lean Healthcare & $\begin{array}{l}\text { Map and analyze the direct flows of Pharmaceutical } \\
\text { Service, aiming at reducing losses and optimizing } \\
\text { processes. }\end{array}$ & $\begin{array}{l}\text { Elaboration and application of questionnaires in qualitative } \\
\text { and quantitative interviews to determine the vision of value } \\
\text { from the employees of the District Pharmacies. }\end{array}$ \\
\hline Reverse Logistics & $\begin{array}{l}\text { Map and analyze the reverse flows of the AF, aiming at loss } \\
\text { reduction and optimization of the processes. }\end{array}$ & $\begin{array}{l}\text { Participation in the meetings of the Working Group } \\
\text { to prepare the Municipal Waste Plan. Elaboration and } \\
\text { application of questionnaires in qualitative and quantitative } \\
\text { interviews with stakeholders of FA. }\end{array}$ \\
\hline Indicadores & $\begin{array}{l}\text { Identify and analyze the performance indicators used in } \\
\text { the Porto Alegre PA }\end{array}$ & $\begin{array}{l}\text { Identification of the indicators present in official } \\
\text { publications and of the operational indicators used during } \\
\text { the direct and reverse flows }\end{array}$ \\
\hline
\end{tabular}

since the density of connections that it made with the others made DP a critical point of the process when observed from the systemic view. The COORAF team met with regard to both the suggestions for modifications and the implementation of these and, after that, another meeting was scheduled to adapt the old flow to the resulting current scenario, as shown in Table 5.

The density of connections that the pharmacist from District Pharmacy (DP) manages to reduce after the new setup is a direct result of the NVA flow building and application process, and will certainly encourage other changes. At first, the change may not seem considerable considering only the tables presented, however, it is possible to analyze and compare the overview of the programming and distribution processes of the PA drugs of the city of Porto Alegre in Figures 1 and 2, which represent the flows before and after the changes, respectively.

It is important to note that other changes were made in the flows, as can be seen in Figure 2, however, it was not yet possible to validate such changes and, therefore, it was decided to present only what concerns the District Pharmacy in Programming and Dispensing. The current phase of the project seeks confirmation of the flows constructed and also the recognition and clarification of them by the APS employees.

The different representations indicate the overlapping of tasks in different sectors, the overload of work of certain parties involved, unnecessary flows and mis-distribution of responsibilities among leaders, is what seems to occur in District Pharmacies, which have many relations (Figure 1), in addition to a large demand for care, which generates a queue and a long waiting time, factors observed in visits to the selected District Pharmacies. Flows considered critical to the success of the system include those that provide access to the drug and pharmaceutical care because they represent value to both COORAF managers and the user. They are: an overview of the processes of programming and distribution of medicines, from the PA of the municipality of Porto Alegre in Figure 1.
After presentation of the individual flows to the COORAF team, the members themselves could observe failures and overloads contained in the current system that could, if changed, result in considerable gains for the whole network, directly or indirectly, especially for COORAF, $\mathrm{CAF}$ and DP. The analysis generated a restructuring of Pharmaceutical Service in the Municipality of Porto Alegre, as shown in figures 3 and 4 . The changes were concentrated in two points considered by the managers of COORAF as more critical: the District Pharmacies and the Supportive Pharmacists.

District Pharmacies, in general, receive a great demand from the population and report problems related to human resources, which has generated service problems such as long waiting times. Supportive Pharmacists act at the tactical level, serving as a bridge between the strategic level of COORAF and the operational level of the District Pharmacies and Health Units. In the initial mapping there were 8 supporting pharmacists who were allocated in the District Pharmacies and, given the great demand of the activities of the DP, ended up operating at the operational level.

With the restructuring (Figure 2) there was a decrease in the attributions of the District Pharmacies, which softened the burden of information and work that went through the District Pharmacy. There was also a restructuring of Supportive Pharmacists, which became only 3 and were allocated to COORAF, acting more closely to coordination. The other 5 pharmacists who acted as supporters were allocated to District Pharmacies that presented more personnel shortages.

Figure 4 shows that 3 supporting pharmacists were relocated to the Coordination of Pharmaceutical Care concentrating drug programming efforts in COORAF. Each district pharmacy also had two pharmacists responsible for dispensing activities that represent a heavy workload for only one pharmacist. In the previous configuration there was a mix of roles between supportive pharmacists and those in charge of the district pharmacy. Such reconfiguration was carried out without the hiring of new professionals, 


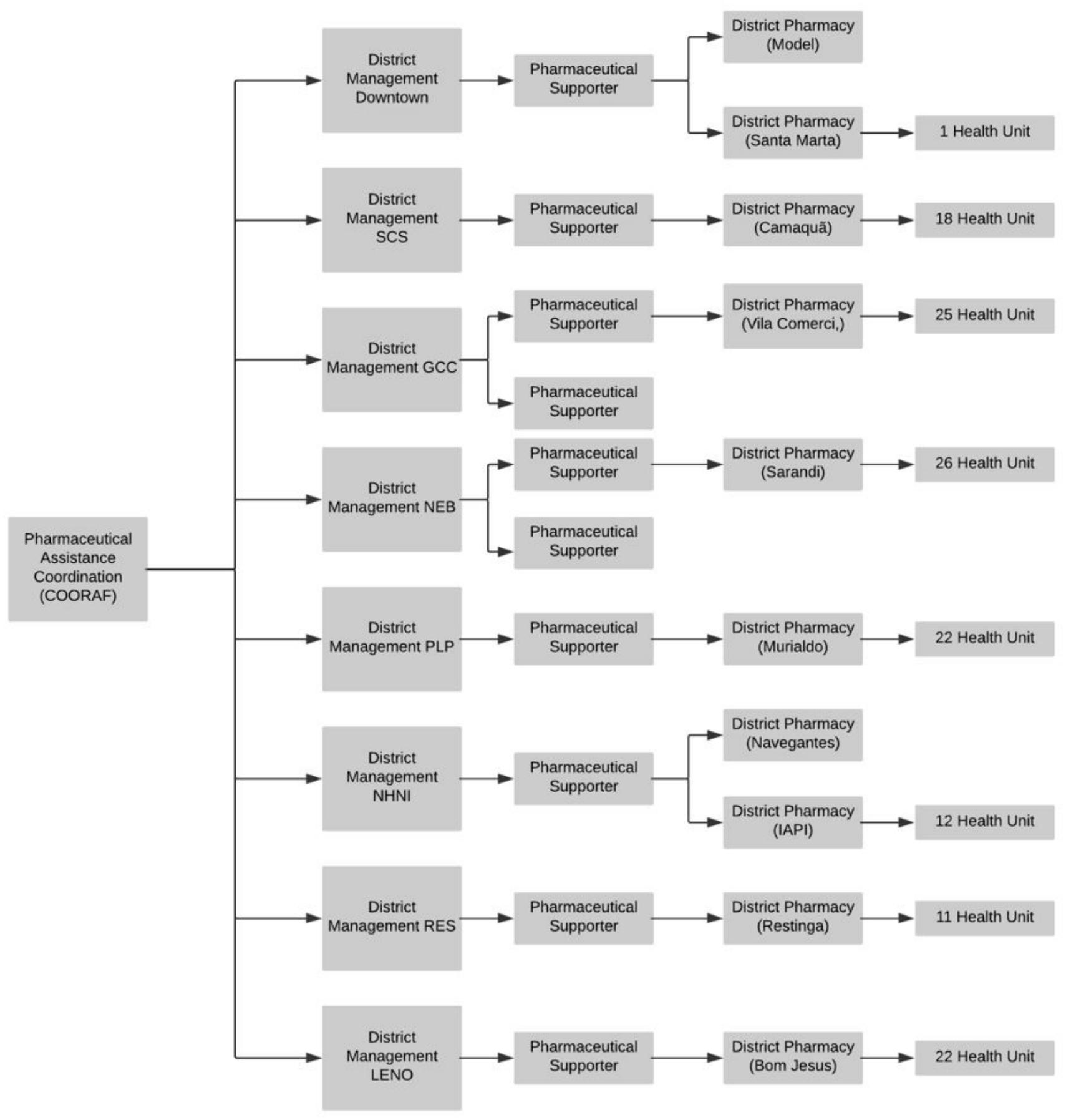

Figure 3. Pharmaceutical Service Organization Table: Before Modification. Source: COORAF Reports.

representing zero cost. The first results of this modification associated with the implementation of digital control systems in the Health Units led to cost reduction of R $\$ 6$ million in the period of 8 months. The details and developments of the causes of such an economy are currently being investigated.

Thus, it will be possible not only to validate the flows, to make them aware not only of their role within the network, but also to perceive improvements related to the whole, as was the case presented by the District Pharmacy.
Network Value Analysis, although designed for business network representation was very effective in the network design of the analyzed health process. The participants quickly understood the use of the tool and the results are very promising considering the optimization of the tangible and intangible flows of this system. Other tools that could have been used to carry out this stage of the project would be the Value Stream Mapping (VSM) and the Functional Resonance Analysis Method (FRAM), mainly because they 


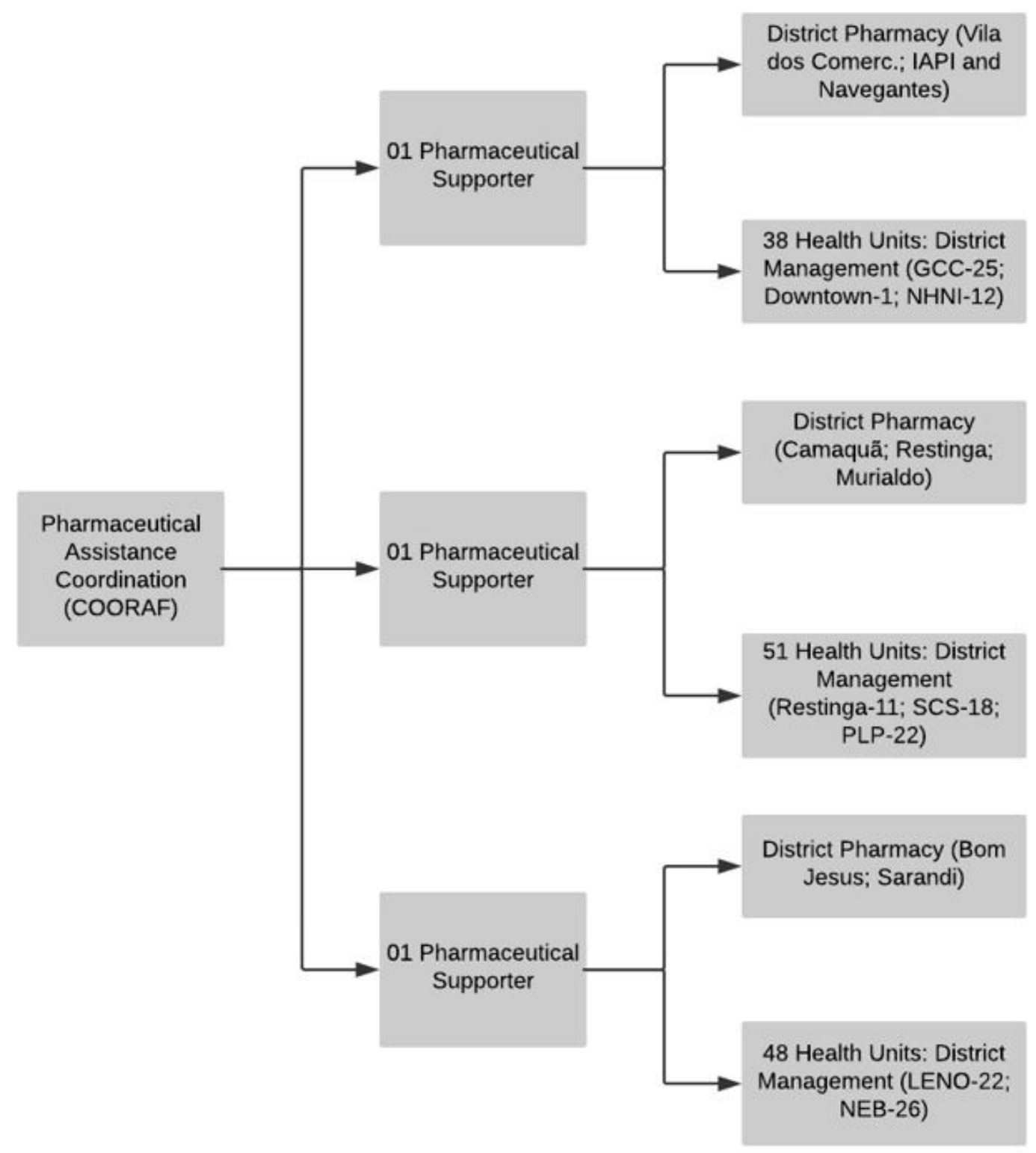

Figure 4. Pharmaceutical Service Organization Table: After Modification. Source: COORAF Reports.

present a greater number of reports in the health related literature. However, the NVA was chosen because of its high adaptability of application and ease of understanding from the implementation of the tool to the resulting analysis.

Some implications that this application has brought to the research, which is still ongoing, are described below. For the project team, the representations obtained revealed the complexity of the system and allowed to visualize at least three large blocks of contents to be worked on the system: improvements using the Lean Healthcare methodology; reverse logistics of medicines both internally and externally to the system and the opportunity to analyze indicators for optimization of all processes. In this way, it was decided to divide the work team on these three fronts as described in Table 5.
Among the future tasks of the work fronts can be cited: validation of the mapping performed with the help of COORAF; flow detailing from qualitative and quantitative interviews; workshops for the development of metrics and indicators.

\section{Conclusion}

This paper presented the report of an experiment still underway to build the value chain of Pharmaceutical Service in the city of Porto Alegre. For reasons of strategic alignment with the demands of COORAF managers, the process has been carried out quickly. The meetings have been productive and those involved are engaged. It is not always possible to find a scenario like this in health institutions, given the intense work routine they face. 
The NVA proved to be a useful tool in the analysis of the complexity of health processes if the adaptation of the initial phase of the application was obeyed, as shown in the results of the article. These findings feed the literature with an unconventional application for the tool in the health environment. The practical contribution is to provide a systemic view for network actors as a basis for optimizing processes in terms of tangible and intangible flows.

One of the findings of this application of NVA is the small contingent of managers in COORAF to coordinate the entire PA system in the municipality. The visual representation obtained serves as an instrument, not only to illustrate the need to hire/relocate personnel between the functions of the sub processes of the PA, but also to make decisions, allocate personnel, analyze indicators and control the improvement projects that will be carried out in the sequence.

It is interesting to observe the involvement of teams that participated, directly or indirectly, in the construction of the tangible and intangible flows of the value network and their reactions during the application of the chosen tool. The progress of the project, despite the traditional occupations of all agents, is considered to be of rapid and effective success, including even changes in the initiative flows of COORAF's own management after the awareness of the systemic vision built during the project, as mentioned previously. In addition, we believe that the next stages of analysis will reveal even more opportunities for optimizing flows, mainly from the awareness of the stakeholders of the network that compose.

The adaptation of the tool showed its suitability to health service processes, suggesting its adaptability to other similar processes. The team of managers easily understood the operation of the tool, and can use it in future management situations in COORAF. It is understood that the application will serve as a model for future practical applications in this or other service / business segments, as well as contribute to the literature demonstrating the feasibility of application in processes other than manufacturing.

\section{Acknowledgements}

We thank the managers of COORAF-POA for their openness and availability in carrying out the research.

\section{References}

ASSOCIATION FRANÇAISE DE NORMALISATION AFNOR. NF EM 12973. La Plaine Saint-Denis Cedex: AFNOR, 2000.

BRASIL. Ministério da Saúde. Conselho Nacional de Saúde. Resolução n 338 , de 06 de maio de 2004. Aprova a Política Nacional de Assistência Farmacêutica. Diário Oficial da
República Federativa do Brasil, Brasília, DF, 20 maio 2004. Seção 1, n. 96.

BRASIL. Ministério da Saúde. Portaria GM/MS n.204, de 29 de janeiro de 2007. Regulamenta o financiamento e a transferência dos recursos federais para as ações e os serviços de saúde, na forma de blocos de financiamento, com o respectivo monitoramento e controle. Diário Oficial da República Federativa do Brasil, Brasília, DF, 2007.

BRASIL. Lei n ${ }^{\circ} 13.021$, de 8 de agosto de 2014. Dispõe sobre o exercício e a fiscalização das atividades farmacêuticas. Diário Oficial da República Federativa do Brasil, Brasília, DF, 11 ago. 2014.

BRASIL. Portaria ${ }^{\circ} 2.436$, de 21 de setembro de 2017. Aprova a Política Nacional de Atenção Básica, estabelecendo a revisão de diretrizes para a organização da Atenção Básica, no âmbito do Sistema Único de Saúde (SUS). Diário Oficial da República Federativa do Brasil, Brasília, DF, 22 set. 2017. n. 183.

DONALDSON, K. M.; ISHII, K.; SHEPPARD, S. D. Customer value chain analysis. Research in Engineering Design, 2006.

FJELDSTAD, O. D.; KetElS, C. H. M. Competitive advantage and the value network configuration: making decisions at a swedish life insurance company. Long Range Planning: Elsevier, 2006.

INSTITUTO BRASILEIRO DE GEOGRAFIA E ESTATÍSTICA - IBGE. Cidades. 2018. Available from: $<$ https://cidades.ibge.gov.br/>. Access in: 19 June 2018.

PAPADOPOULOS, A. N. et al. Design and implementation of processes for the primary care in the healthcare system of Greece. In: INTERNATIONAL CONFERENCE ON BIOINFORMATICS AND BIOENGINEERING (BIBE), 15., Belgrade, Serbia. Proceedings... 2015. USA: IEEE.

PEPPEARD, J.; RYLANDER, A. from value chain to value network: insights for mobile operators. European Management Journal, v. 24, n. 2, p. 128-141, 2006.

PINTO, C. D. B. S.; OSORIO-DE-CASTRO, C. G. S. Gestão da Assistência Farmacêutica e demandas judiciais em pequenos municípios brasileiros: um estudo em Mato Grosso do Sul. Saúde em Debate, v. 39, p. 171-183, 2015.

PORTER, M. Vantagem competitiva: criando e sustentando um desempenho superior. Rio de Janeiro: Elsevier, 1989.

PORTER, M. What is value in health care? The New England Journal of Medicine, v. 363, p. 2477-2481, 2010.

ROCHA, W.; BORINELLI, M. L. Análise estratégica de cadeia de valor: um estudo exploratório do segmento indústriavarejo. RCC, ano 4, v. 1, n. 7, jan.-jun, 2007, p. 145-165. 